\title{
PENINGKATAN PRESTASI BELAJAR SISWA MATA PELAJARAN PKN MELALUI MODEL PEMBELAJARAN TREFFINGER PADA SISWA KELAS IV SDN BRINGIN
}

\author{
Ramijan \\ Sekolah Dasar Negeri (SDN) Bringin Kab. Tuban, Indonesia
}

\begin{abstract}
Abstrak. Model pembelajaran Treffinger pada mata pelajaran PKn diharapkan mampu meningkatkan prestasi belajar siswa SD. Tujuan dari penelitian ini adalah (a) mengetahui penerapan model pembelajaran Treffinger pada mata pelajaran PKn pokok bahasan sistem pemerintahan desa dan pemerintah kecamatan? (b) mengetahui apakah penerapan model pembelajaran Treffinger dapat meningkatkan prestasi belajar siswa kelas IV SDN Bringin tahun pelajaran 2014/2015? (c) mengetahui aktifitas dan minat belajar siswa kelas IV SDN Bringin tahun pelajaran 2014/2015 terhadap pelajaran PKn dengan diterapkannya model pembelajaran Treffinger? Penelitian ini menggunakan desain penelitian yang digunakan adalah One Group pretest-Posttest desaign dan penelitian tindakan (action research) sebanyak 2 putaran. Setiap putaran terdiri dari empat tahap yaitu: rancangan, kegiatan dan pengamatan, refleksi, dan refisi. Sampel penelitian ini adalah kelas IV SDN Bringin tahun pelajaran 2014/2015. Hasil penelitian menunjukan bahwa nilai rata-rata peningkatan prestasi belajar siswa mengalami kenaikan yang signifikan. Hal ini ditunjukan oleh nilai rata-rata gain skor yang dinormalisasi siklus I sebesar 0,35 dengan kriteria sedang dan siklus I sebesar 0,71 dengan kriteria tinggi.
\end{abstract}

Kata Kunci: Pembelajaran PKn, Model Pembelajaran Treffinger, Prestasi Belajar Copyright (C 2017 Madrasah Jurnal Pendidikan dan Pembelajaran Dasar. All Right Reserved

\section{A. PENDAHULUAN}

Pemerintah melalui Kementerian Pendidikan Nasional sudah mencanangkan penerapan pendidikan karakter untuk semua tingkat pendidikan dari SD sampai Perguruan Tinggi. Menurut Muhammad Nuh (Sri Narwani, 2011: 1) pembentukan karakter perlu dilakukan sejak usia dini. Jika karakter sudah terbentuk sejak usia dini maka tidak akan mudah untuk mengubah karakter seseorang. Ia juga berharap, pendidikan karakter dapat membangun kepribadian bangsa.

Usia sekolah dasar (sekitar umur 6 - 12 tahun) merupakan tahap penting bagi pelaksanaan pendidikan karakter, bahkan hal yang fundamental bagi kesuksesan perkembangan karakter peserta didik. Sigit Dwi K. (2007: 121) menyatakan anak sekolah dasar mengalami perkembangan fisik dan motorik tak terkecuali perkembangan kepribadian, watak emosional, intelektual, bahasa, budi pekerti, dan moralnya yang bertumbuh pesat. Oleh karena itu jika menghendaki pendidikan karakter dapat berhasil maka pelaksanaannya harus dimulai sejak masa kanak-kanak dan usia SD.

Banyaknya tindakan amoral yang dilakukan peserta didik seperti mencontek, tawuran, membolos dan tindakan lainnya mengindikasikan bahwa pendidikan formal gagal dalam membentuk karakter peserta didik. Sjarkawi (2006: 45) menyatakan bahwa

Vol. 9 No. 2, Juni 2017

Madrasah homepage: http://ejournal.uin-malang.ac.id/index.php/madrasah/index 
perilaku dan tindakan amoral disebabkan oleh moralitas yang rendah. Moralitas yang rendah antara lain disebabkan oleh pendidikan moral di sekolah yang kurang efektif.

Pendidikan Kewarganegaraan merupakan salah satu konsep pendidikan yang berfungsi untuk membentuk siswa sebagai warga negara yang mempunyai karakter. Keterkaitan Pendidikan Kewarganegaraan terhadap pengembangan karakter dikemukakan oleh Samsuri (2011: 20) yang menyatakan Pendidikan Kewarganegaraan memiliki dimensi-dimensi yang tidak bisa dilepaskan dari aspek pembentukan karakter dan moralitas publik warga negara.

Terkait dengan prestasi dan hasil belajar siswa terhadap suatu pelajaran menjadi kurang baik salah satu penyebabnya adalah penyampaian materi yang kurang menarik minat siswa, sehingga tujuan pembelajaran untuk melatih cara berfikir secara sistematis, logis, kritis, kreatif dan konsisten tidak tercapai secara maksimal.

Pada pembelajaran PKn, sebelumnya peneliti telah menggunakan model ceramah dan tugas, namun hal tersebut masih belum memberikan hasil yang memuaskan dengan perolehan nilai siswa seperti pada tabel 1.1 di bawah ini.

Tabel A.1 Nilai Siswa Prasiklus

\begin{tabular}{|ccc|}
\hline No & Iterval Kelas & Frekuensi \\
\hline 1. & $\leq 69$ & 9 \\
\hline 2. & $70-79$ & 6 \\
\hline 3. & $80-89$ & 3 \\
\hline 4. & $\geq 90$ & 2 \\
\hline
\end{tabular}

Dari data di atas dapat simpulkan bahwa ketuntasan siswa dalam pembelajaran PKn masih rendah atau tidak signifikan kalau menggunakan model ceramah dan penugasan untuk meningkatkan prestasi belajar siswa. Untuk meningkatkan kualitas proses dan hasil dalam pembelajaran PKn di SDN Bringin, penulis mencoba menerapkan pendekatan pembelajaran yang lebih mengaktifkan siswa yaitu pembelajaran model Treffinger. Model pembelajaran ini merupakan pembaruan dari model Creative Problem Solving (CPS) atau sering disebut dengan Creative Problem Solving Version 6.1 (CPS v6.1). Model Treffinger mengajak siswa berpikir kreatif dalam menghadapi masalah, seperti yang dikemukakan Treffinger (dalam Huda 2003:1) "Creative Problem Solving version 6.1 is a model to help you solve problems and manage change creatively. It gives you a set of easy to use tools to help translate your goals and dreams into reality".

Sedangkan menurut Huda, (2013:321) manfaat yang dapat diperoleh melalui penggunaan model pembelajaran Treffinger meliputi: (a) memberi kesempatan kepada siswa untuk memahami konsep-konsep dengan cara menyelesaikan suatu permasalahan; (b) membuat siswa aktif dalam pembelajaran; (c) mengembangkan kemampuan berpikir siswa karena disajikan masalah pada awal pembelajaran dan memberi keleluasaan pada siswa untuk mencari arah-arah penyelesaiannya sendiri; (d) mengembangkan kemampuan siswa untuk mendefinisikan masalah, mengumpulkan data, menganalisis data, membangun hipotesis, dan memecahkan suatu permasalahan; dan (e) membuat siswa menerapkan pengetahuan yang sudah dimilikinya ke alam situasi baru.

Penggunaan model pembelajaran Treffinger, diharapkan dapat meningkatkan prestasi dan aktivitas siswa dalam proses belajar mengajar sehingga dalam proses belajar mengajar itu aktivitasnya tidak hanya didominasi oleh guru, dengan demikian siswa akan terlibat secara fisik, emosional dan intelektual yang pada gilirannya diharapkan konsep

Vol. 9 No. 2, Juni 2017

Madrasah homepage: http://ejournal.uin-malang.ac.id/index.php/madrasah/index 


\section{MADRASAH}

Jurnal Pendidikan dan Pembelajaran Dasar

p ISSN: 1979-5599 | e ISSN: 2502-194X

P a g e

sistem pemerintahan desa dan pemerintah kecamatan yang diajarkan oleh guru dapat dipahami oleh siswa.

\section{B. LANDASAN TEORI}

\section{Pembelajaran PKn}

Menurut Branson (1999:7) tujuan civic education adalah partisipasi yang bermutu dan bertanggung jawab dalam kehidupan politik dan masyarakat baik tingkat lokal, negara bagian, dan nasional. Tujuan pembelajaran PKn dalam Depdiknas (2006:49) adalah untuk memberikan kompetensi sebagai berikut:

a. Berpikir kritis, rasional, dan kreatif dalam menanggapi isu Kewarganegaraan.

b. Berpartisipasi secara cerdas dan tanggung jawab, serta bertindak secara sadar dalam kegiatan bermasyarakat, berbangsa dan bernegara.

c. Berkembang secara positif dan demokratis untuk membentuk diri berdasarkan karakter-karakter masyarakat di Indonesia agar dapat hidup bersama dengan bangsabangsa lain.

d. Berinteraksi dengan bangsa-bangsa lain dalam peraturan dunia secara langsung dengan memanfaatkan teknologi informasi dan komunikasi.

Lebih lanjut dijelaskan dalam lampiran Permendiknas No 22 tahun 2006 di kemukakan bahwa "Mata Pelajaran Pendidikan Kewarganegaraan merupakan mata Pelajaran yang memfokuskan pada pembentukkan warga negara yang memahami dan mampu melaksanakan hak-hak dan kewajibannya untuk menjadi warga negara Indonesia yang cerdas, terampil, dan berkarekter yang diamanatkan oleh Pancasila dan UUD 1945".

Berdasarkan Pemendiknas No. 22 tahun 2006 ruang lingkup Mata pelajaran Pendidikan Kewarganegaraan untuk Pendidikan Dasar dan Menengah secara umum meliputi aspek-aspek sebagai berikut:

a. Persatuan dan Kesatuan Bangsa, meliputi: hidup rukun dalam perbedaan, Cinta lingkungan, Kebanggaan sebagai bangsa Indonesia, Sumpah Pemuda, Keutuhan Negara Kesatuan Republik Indonesia, Partisipasi dalam pembelaan negara, Sikap positif terhadap Negara Kesatuan.

b. Norma Hukum dan Peraturan, meliputi: tertib dalam kehidupan keluarga, Tata tertib di sekolah, Norma yang berlaku di masyarakat, Peraturan-peraturan daerah, Normanorma dalam kehidupan berbangsa dan bernegara, Sistim hukum dan peradilan nasional, Hukum dan peradilan internasional.

c. Hak Asasi Manusia, meliputi: hak dan kewajiban anak, Hak dan kewajiban anggota masyarakat, Instrumen nasional dan internasional HAM, Pemajuan, penghormatan dan perlindungan HAM.

d. Kebutuhan Warga Negara, meliputi: hidup gotong royong, Harga diri sebagai warga masyarakat, Kebebasan berorganisasi, Kemerdekaan mengeluarkan pendapat, Menghargai keputusan bersama, Prestasi diri, Persamaan kedudukan warga negara.

e. Konstitusi Negara, meliputi: proklamasi kemerdekaan dan konstitusi yang pertama, Konstitusi-konstitusi yang pernah digunakan di Indonesia, Hubungan dasar negara dengan konstitusi.

f. Kekuasaan dan Politik, meliputi: pemerintahan desa dan kecamatan, Pemerintahan daerah dan otonomi, Pemerintah pusat, Demokrasi dan sistem politik, Budaya politik, Budaya demokrasi menuju masyarakat madani, Sistem pemerintahan, Pers dalam masyarakat demokrasi.

Vol. 9 No. 2, Juni 2017

Madrasah homepage: http://ejournal.uin-malang.ac.id/index.php/madrasah/index 
g. Pancasila, meliputi: kedudukan Pancasila sebagai dasar negara dan ideologi negara, Proses perumusan Pancasila sebagai dasar negara, Pengamalan nilai-nilai Pancasila dalam kehidupan sehari-hari, Pancasila sebagai ideologi terbuka.

h. Globalisasi, meliputi: globalisasi di lingkungannya, Politik luar negeri Indonesia di era globalisasi, Dampak globalisasi, Hubungan internasional dan organisasi internasional, dan Mengevaluasi globalisasi.

\section{Prestasi Belajar}

Menurut Poerwodarminto (2002: 768), prestasi belajar adalah hasil yang dicapai (dilakukan, dekerjakan), dalam hal ini prestasi belajar merupakan hasil pekerjaan, hasil penciptaan oleh seseorang yang diperoleh dengan ketelitian kerja serta perjuangan yang membutuhkan pikiran.

Berdasarkan uraian di atas dapat dikatakan bahwa prestasi belajar yang dicapai oleh siswa dengan melibatkan seluruh potensi yang dimilikinya setelah siswa itu melakukan kegiatan belajar. Pencapaian hasil belajar tersebut dapat diketahui dengan megadakan penilaian tes hasil belajar. Penilaian diadakan untuk mengetahui sejauh mana siswa telah berhasil mengikuti pelajaran yang diberikan oleh guru. Di samping itu guru dapat mengetahui sejauh mana keberhasilan guru dalam proses belajar mengajar di sekolah.

Sejalan dengan prestasi belajar, maka dapt diartikan bahwa prestasi belajar PKn adalah nilai yang dipreoleh siswa setelah melibatkan secara langsung/aktif seluruh potensi yang dimilikinya baik aspek kognitif (pengetahuan), afektif (sikap) dan psikomotor (keterampilan) dalam proses belajar mengajar PKn.

\section{Pembelajaran Treffinger}

Model pembelajaran Treffinger adalah poses pembelajaran yang mengupayakan suatu proses belajar mengajar yang dibuat sekomunikatif mungkin sehingga suasana belajar menjadi menyenangkan bagi siswa.

Menurut Huda (2013: 318) bahwa model Treffinger didasari dengan adanya perkembangan zaman yang terus berubah dengan cepat dan semakin kompleksnya permasalahan yang harus dihadapi. Karena itu, untuk mengatasi permasalahan tersebut diperlukan suatu cara agar dapat menyelesaikan suatu permasalahan dan menghasilkan solusi yang tepat. Yang perlu diperhatikan untuk mengatasi hal tersebut adalah dengan memperhatikan fakta-fakta penting yang ada di lingkungan sekitar lalu memunculkan berbagai gagasan dan memilih solusi yang tepat untuk kemudian diimplementasikan. Sesuai dengan hal tersebut maka pelaksanaan model Treffinger diharapkan mampu meningkatkan kemampuan pemecahan masalah dan meningkatkan minat siswa dalam mengikuti pembelajaran PKn.

Model Treffinger terdiri atas 3 (tiga) komponen penting, yaitu understanding challenge, generating ideas, dan preparating for action.

Vol. 9 No. 2, Juni 2017

Madrasah homepage: http://ejournal.uin-malang.ac.id/index.php/madrasah/index 


\section{MADRASAH}

Jurnal Pendidikan dan Pembelajaran Dasar

p ISSN: 1979-5599 | e ISSN: 2502-194X

P a g e

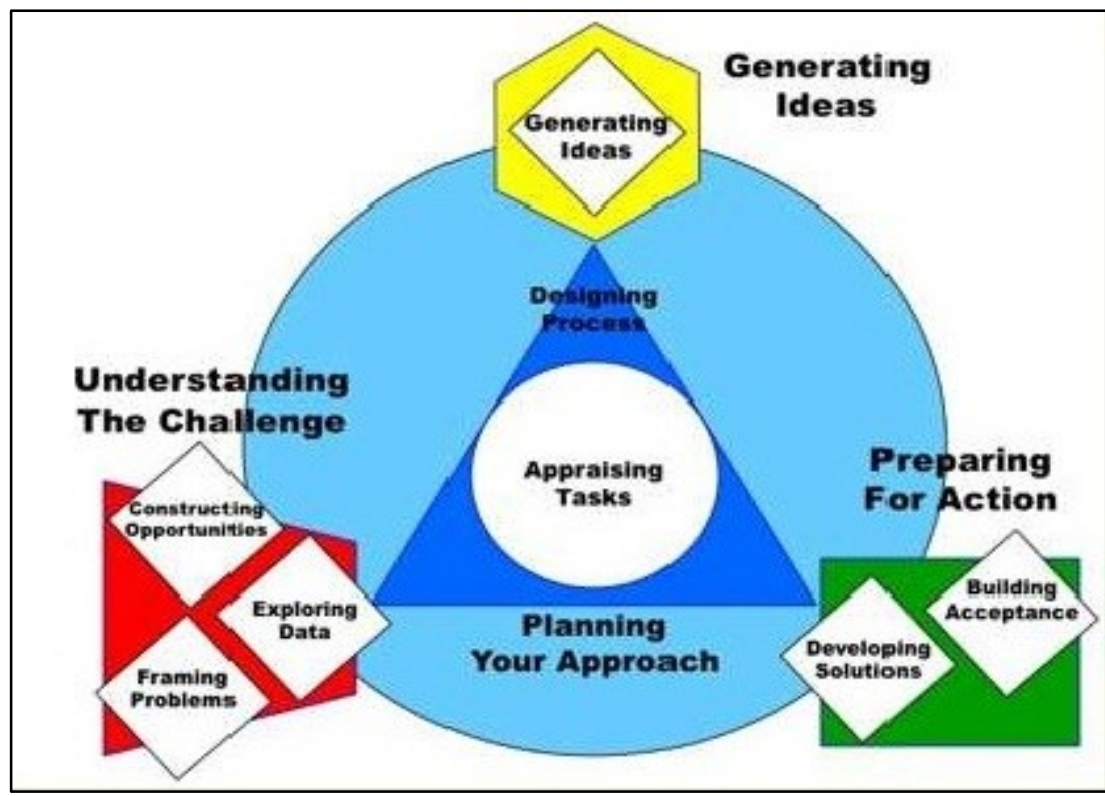

Gambar B.1 Komponen Model Treffinger (Treffinger, 2007: 8)

Treffinger (dalam Huda, 2013:318) menjelaskan langkah-langkah model Treffinger sebagai berikut:

\section{Komponen I - Understanding Challenge (memahami tantangan)}

a. Menentukan tujuan: Guru menginformasikan kompetensi yang harus dicapai dalam pembelajarannya

b. Menggali data: Guru mendemonstrasikan/menyajikan fenomena alam yang dapat mengundang keingintahuan

c. Merumuskan masalah: Guru memberi kesempatan kepada siswa untuk mengidentifikasi permasalahan

Komponen II - Generating Ideas (Membangkitkan gagasan). Memunculkan gagasan: Guru memberi waktu dan kesempatan pada siswa untuk mengungkapkan gagasannya dan juga membimbing siswa untuk menyepakati alternatif pemecahan yang akan diuji

\section{Komponen III - Preparing for Action (Mempersiapkan tindakan)}

a. Mengembangkan solusi: Guru mendorong siswa untuk mengumpulkan informasi yang sesuai

b. Membangun penerimaan: Guru mengecek solusi yang telah diperoleh siswa

\section{Kelebihan dan Kelemahan Model Treffinger}

Sebagaimana model-model pembelajaran lainnya, model pembelajaran Treffinger memiliki berbagai kelebihan dan kekurangan. Sarson (dalam Huda, 2013: 320) menyatakan bahwa karakteristik yang paling dominan dari model pembelajaran Treffinger adalah upayanya dalam mengintegrasikan dimensi kognitif dan afektif siswa untuk mencari araharah penyelesaian yang akan ditempuhnya untuk memecahkan permasalahan. Manfaat yang bisa diperoleh dari menerapkan model Treffinger adalah: (1) memberi kesempatan kepada siswa untuk memahami konsep-konsep dengan cara menyelesaikan suatu permasalahan; (2) membuat siswa aktif dalam pembelajaran; (3) mengembangkan kemampuan berpikir siswa karena disajikan masalah pada awal pembelajaran dan memberi keleluasaan pada siswa untuk mencari arah-arah penyelesaiannya sendiri; (4) mengembangkan kemampuan siswa untuk mendefinisikan masalah, mengumpulkan data, 
menganalisis data, membangun hipotesis, dan memecahkan suatu permasalahan; dan (5) membuat siswa menerapkan pengetahuan yang sudah dimilikinya ke alam situasi baru. (Huda, 2013: 321)

Selain memiliki kelebihan, model Treffinger juga memiliki kelemahan, diantaranya: (1) adanya perbedaan level pemahaman dan kecerdasan siswa dalam menghadapi masalah; (2) ketidaksiapan siswa untuk menghadapi masalah baru yang dijumpai di lapangan; (3) model ini mungkin tidak terlalu cocok diterapkan untuk siswa kanak-kanak atau kelas-kelas awal Sekolah Dasar; dan (4) membutuhkan waktu yang tidak sebentar untuk mempersiapkan siswa melakukan tahapan-tahapan dalam model Treffinger. (Huda, 2013: 321)

\section{METODOLOGI PENELITIAN}

\section{Rancangan dan Desain Penelitian}

Rancangan pada dasarnya adalah merupakan keseluruhan proses, ia merupakan landasan berpijak, serta dapat pula di jadikan dasar penilaian, baik oleh peneliti sendirimaupun orang lain (Margono,2005:100). Menurut Nazir (1999:98) rancangan penelitian merupakan rancangan kegiatan yang di tempuh dalam merencanakan peneliti.

Penelitian ini bertujuan untuk mengetahui implementasi model pembelajaran Treffinger terhadap peningkatan prestasi belajar siswa pada mata pelajaran Pkn kelas IV SDN Bringin tahun pelajaran 2014/2015. Metode yang digunakan dalam penelitian ini adalah metode quasi eksperimen dengan desain One Group Pretest Posttest design yaitu penelitian eksperimen yang dilaksanakan pada satu kelompok saja yang dinamakan kelompok eksperimen tanpa ada kelompok pembanding atau kelompok kontrol. Desain ini dapat digambarkan sebagai berikut

Tabel C.1 Desain Penelitian One Group Pretest Posttest Design

\begin{tabular}{|cccc|}
\hline Kelompok & Pre Test & Treatmen & Postest \\
\hline Eksperimen & $\mathrm{T}_{0}$ & $\mathrm{X}$ & $\mathrm{T}_{1}$ \\
\hline
\end{tabular}

Percobaan ini dilakukan untuk melihat kebaikan sistem mengajar dengan menggunakan model pembelajaran Treffinger. Metode mengajar dengan model Treffinger adalah suatu perlakuan (treatment) X. Pertama-tama diukur mean prestasi belajar dengan pretest $\mathrm{T}_{0}$ sebelum perlakuan $\mathrm{X}$ dikenakan. Pretest $\mathrm{T}_{0}$ mengunakan data hasil pretest tes fomatif, sedangkan post-test $\mathrm{T}_{1}$ data hasil ulangan/tes formatif siklus I dan siklus II.

Sesudah perlakuan $\mathrm{X}$ dikenakan, diukur kembali mean prestasi belajar tersebut dengan menggunakan pretest $\mathrm{T}_{0}$. Kemudan dibuat perbandingan antara maen prestasi belajar pretest $\mathrm{T}_{0}$ dan post-test $\mathrm{T}_{1}$ untuk melihat bagaimana pengaruh belajar dengan menggunakan model pembelajaran Treffinger tersebut.

\section{Populasi dan Sampel}

Populasi dalam penelitian ini adalah seluruh siswa kelas IV SDN Bringin Kecamatan Montong Kabupaten Tuban tahun pelajaran 2014/2015sebanyak 20 orang.

Sampel merupakan wakil dari keseluruhan subjek penelitian. Dalam pengambilan sampel pada penelitian ini berdasarkan pendapat Arikunto (2001:120) menjelaskan bahwa, "Apabila subjeknya kurang dari 100 lebih baik diambil semua hingga penelitiannya merupakan penelitian populasi. Selanjutnya jika jumlah subjeknya besar dapat diambil antara $10-15 \%$, atau $20-25 \%$ atau lebih".

Vol. 9 No. 2, Juni 2017

Madrasah homepage: http://ejournal.uin-malang.ac.id/index.php/madrasah/index 


\section{MADRASAH}

Jurnal Pendidikan dan Pembelajaran Dasar

p ISSN: 1979-5599 | e ISSN: 2502-194X

P a g e

Berdasarkan pendapat tersebut maka pengambilan sampel menggunakan teknik total sampling atau sampel jenuh. Dengan demikian sampel dalam penelitian adalah seluruh siswa kelas IV SDN Bringin Kecamatan Montong Kabupaten Tuban tahun pelajaran 2014/2015 sebanyak 20 orang sebagai kelompok eksperimen

\section{Instrumen Penelitian}

Instrumen penelitian adalah alat yang digunakan oleh peneliti dalam mengumpulkan data agar pekerjaannya lebih mudah dan hasilnya lebih baik, dalam arti lebih cermat, lengkap, dan sistematis sehingga lebih mudah diolah.

Instrumen untuk mengumpulkan data PTK dapat dipahami dari dua sisi, yaitu sisi proses dan sisi hal yang diamati (Susilo Kisyani, 2006). (1) Dari sisi Proses instrumen dalam PTK harus dapat menjangkau masalah yang berkaitan dengan input (kondisi awal), proses (saat berlangsung), dan output (hasil). (2) Dari sisi hal yang diamati, instrument dapat digolongkan menjadi tiga, yaitu: (a) Pengamatan terhadap guru (Observing Teacher); (b) Pengamatan terhadap kelas (Observing Classrooms); dan (c) Pengamatan terhadap peserta didik (Observing Student).

Instrumen penelitian yang digunakan untuk pengumpulan data dalam penelitian Quasi Eksperimen ini berupa instrumen non-tes dan instrumen tes. Intrumen tes (pretest dan posttest) berupa soal pilihan ganda dengan tiga pilihan jawaban. Dan instrumen non-tes yaitu Silabus, Rencana Pelaksanaan Pembelajaran (RPP), Siswa, dan Lembar Observasi Kegiatan Pembelajaran dan Lembar observasi aktivitas guru dan siswa, untuk mengamati aktivitas guru dan siswa selama proses pembelajaran.

Untuk mengetahui sejauh mana kualitas suatu instrumen tes, maka sebelumnya perlu dilakukan serangkaian pengujian dan analisis terhadap instrumen. Untuk mendapatkan instrumen yang berkualitas dapat ditinjau dari beberapa hal diantaranya uji validitas, uji reliabilitas, uji indeks kesukaran, uji daya pembeda.

\section{Teknik Analisis Data}

Untuk menganalisis tingkat keberhasilan atau persentase keberhasilan siswa setelah proses belajar mengajar setiap putarannya dilakukan dengan cara memberikan evaluasi berupa soal tes tertulis pada setiap akhir putaran. Analisis ini dihitung dengan menggunakan uji statistik sebagai berikut:

\section{Analisis Data Untuk Persyaratan Uji Hipotesis}

\section{a. Uji Normalitas}

Uji normalitas data dimaksudkan untuk memperlihatkan bahwa data sampel berasal dari populasi yang berdistribusi normal. Ada beberapa teknik yang dapat digunakan untuk menguji normalitas data, antara lain uji Chi-Kuadrat, uji Lilliefors, dan uji Kolmogorov-Smirnov. Dalam penelitian ini digunakan uji normalitas KolmogorovSmirnov dengan SPSS Versi 13. Cara mengetahui signifikan atau tidak signifikan hasil uji normalitas adalah dengan memperhatikan bilangan pada kolom signifikansi (Sig.). Untuk menetapkan kenormalan, kriteria yang berlaku adalah sebagai berikut:

1) Tarap signifikansi uji $\alpha=0.05$

2) Membandingkan $p$ dengan taraf signifikansi yang diperoleh

3) Jika signifikansi yang diperoleh $>a$, maka sampel berasal dari populasi yang berdistribusi normal

4) Jika signifikansi yang diperoleh $<\alpha$, maka sampel bukan berasal dari populasi yang berdistribusi normal

Vol. 9 No. 2, Juni 2017

Madrasah homepage: http://ejournal.uin-malang.ac.id/index.php/madrasah/index 


\section{b. Uji Homogenitas Varians}

Uji homogenitas dimaksudkan untuk memperlihatkan bahwa dua atau lebih kelompok data sampel berasal dari populasi yang memiliki variansi yang sama. Pada analisis regresi, persyaratan analisis yang dibutuhkan adalah bahwa galat regresi untuk setiap pengelompokan berdasarkan variabel terikatnya memiliki variansi yang sama.

Pengujian homogenitas varians suatu kelompok data, dapat dilakukan gengan cara: Uji F. Adapun proses pengujian menggunakan Microsoft Excel 2007.

\section{c. Uji Gain Skor Ternormalisasi}

Untuk dapat melihat tingkat efektifitas pembelajaran yang menggunakan model pembelajaran Treffinger dilakukan analisis terhadap gain skor ternormalisasi dengan menggunakan rumus sebagai berikut:

$$
[g]: \frac{\left\{\%\left[S_{f}\right]-\%\left[S_{i}\right]\right\}}{\left\{100-\%\left[S_{i}\right]\right\}}
$$

Dimana : $[g]$ : adalah gain skor ternormalisasi

$\left[S_{f}\right]$ : adalah skor rerata post-test

$\left[S_{i}\right] \quad$ : adalah skor rerata pretest

Tingkat perolehan gain skor ternormalisasi dikategorikan dalam tiga kategori yaitu:

$$
\begin{array}{ll}
\text { g-tinggi } & =[<\mathrm{g}>] \geq 7 \\
\text { g-sedang } & =0,3 \leq[<\mathrm{g}>]<7 \\
\text { g-rendah } & =[<\mathrm{g}>]<0,3 \\
\text { tidak efektif } & =[<\mathrm{g}>]<0
\end{array}
$$

\section{HASIL PENELITIAN \& PEMBAHASAN}

\section{Hasil Analisis Item Butir Soal}

Validitas butir soal dimaksudkan untuk mengetahui kelayakan tes sehingga dapat digunakan sebagai instrument dalam penelitian ini. Dari perhitungan 40 soal diperoleh 20 soal tidak valid dan 25 soal valid. Hasil dari validitas soal-soal dirangkum dalam tabel di bawah ini.

Tabel D.1 Soal Valid dan Tidak Valid Tes Formatif Siswa

\begin{tabular}{|c|c|}
\hline Soal Valid & Soal Tidak Valid \\
\hline $3,5,4,6,8,12,13,14,17,19,21$, & $1,2,7,9,10,11,15,16,18,20$ \\
$22,25,26,29,32,34,36,37,38,40$ & $24,23,27,28,30,31,33,35,39$ \\
\hline
\end{tabular}

Soal-soal yang telah memenuhi syarat validitas diuji reliabilitasnya. Dari hasil perhitungan diperoleh koefisien reliabilitas $\mathrm{r}_{11}$ sebesar 0,744. Harga ini lebih besar dari harga $\mathrm{r}$ product moment. Untuk jumlah siswa $(\mathrm{N}=20)$ dengan $\mathrm{r}(95 \%)=0,625$. Dengan demikian soal-soal tes yang digunakan telah memenuhi syarat reliabilitas. Sedangkan analisis taraf kesukaran digunakan untuk mengetahui tingkat kesukaran soal. Hasil analisis menunjukkan dari 40 soal yang diuji terdapat: 10 soal dengan kriteria mudah, 17 soal kriteria sedang, dan 13 soal dengan kriteria sukar.

Analisis daya pembeda dilakukan untuk mengetahui kemampuan soal dalam membedakan siswa yang berkemampuan tinggi dengan siswa yang berkemampuan rendah.

Dari hasil analisis daya pembeda diperoleh soal yang berkriteria jelek sebanyak 7 soal, berkriteria cukup 14 soal, dan berkriteria baik sejumlah 19 soal. Dengan demikian

Vol. 9 No. 2, Juni 2017

Madrasah homepage: http://ejournal.uin-malang.ac.id/index.php/madrasah/index 


\section{MADRASAH}

Jurnal Pendidikan dan Pembelajaran Dasar

p ISSN: 1979-5599 | e ISSN: 2502-194X

P a g e | 101

soal-soal tes yang digunakan telah memenuhi syara-syarat validitas, reliabilitas, taraf kesukaran, dan daya pembeda.

\section{Hasil Uji Normalitas Data}

Uji normalitas data dimaksudkan untuk memperlihatkan bahwa data sampel berasal dari populasi yang berdistribusi normal. Dari uji normalitas Kolmogorov-Smirnov dengan SPSS Versi 13 diperoleh data sebagai berikut:

Tabel D.2 Tests of Normality

\begin{tabular}{|lcccccc|}
\hline & \multicolumn{3}{c}{ Kolmogorov-Smirnov(a) } & \multicolumn{3}{c|}{ Shapiro-Wilk } \\
\hline & Statistic & $\mathrm{df}$ & \multicolumn{1}{c}{ Sig. } & Statistic & df & Sig. \\
\hline Pretest &, 181 & 20 &, 085 &, 937 & 20 &, 215 \\
\hline $\begin{array}{l}\text { Post- } \\
\text { test1 }\end{array}$ &, 105 & 20 &, $200\left(^{*}\right)$ &, 963 & 20 &, 612 \\
\hline $\begin{array}{l}\text { Post- } \\
\text { test2 }\end{array}$ &, 170 & 20 &, 130 &, 945 & 20 &, 302 \\
\hline
\end{tabular}

* This is a lower bound of the true significance.

a Lilliefors Significance Correction

Keluaran pada tabel 1.3 di atas menunjukkan uji normalitas data pretest, post-test siklus 1 dan post-test siklus 2 yang sudah diuji sebelumnya secara manual dengan uji Lilliefors dan Kolmogorov-Smirnov. Pengujian dengan SPSS berdasarkan pada uji Kolmogorov-Smirnov. Hipotesis yang diuji adalah:

H0 : Sampel berasal dari populasi berdistribusi normal

H1 : Sampel tidak berasal dari populasi berdistribusi normal

Pada hasil di atas diperoleh taraf signifikansi dan untuk kelompok pretest : $(0,085)$, post-test siklus $1:(0,200)$ dan post-test siklus $2: 0.130$. dengan demikian, data berasal dari populasi yang berdistribusi normal, pada taraf signifikansi 0.05. kesimpulan uji normalitas bahwa data sangat signifikan untuk suatu taraf signifikasi $(a)=0.05$.

\section{Hasil Uji Homogenitas Varians}

Uji homogenitas dimaksudkan untuk memperlihatkan bahwa dua atau lebih kelompok data sampel berasal dari populasi yang memiliki variansi yang sama. Pada analisis regresi, persyaratan analisis yang dibutuhkan adalah bahwa alat regresi untuk setiap pengelompokan berdasarkan variabel terikatnya memiliki variansi yang sama.

Hasil pengujian homogenitas varians suatu kelompok data, dilakukan gengan cara Uji F. Adapun proses pengujian menggunakan Microsoft Excel 2007 seperti pada tabel 1.4 dan 1.5 di bawah ini.

Tabel D.3 F-Test Two-Sample for Variances Siklus I

\begin{tabular}{|c|c|c|}
\hline & Pretest & $\begin{array}{c}\text { Post-test Siklus } \\
I\end{array}$ \\
\hline Mean & 66,8 & 77,8 \\
\hline Variance & 121,957895 & 93,43157895 \\
\hline Observations & 20 & 20 \\
\hline$d f$ & 19 & 19 \\
\hline$F$ & 1,30531771 & \\
\hline$P(F<=f)$ one-tail & 0,283564 & \\
\hline F Critical one-tail & 2,1682516 & \\
\hline
\end{tabular}

Vol. 9 No. 2, Juni 2017

Madrasah homepage: http://ejournal.uin-malang.ac.id/index.php/madrasah/index 
Kesimpulan yang didapat pada tabel di atas adalah: F adalah Fh (F-hitung) yaitu: 1,30531771 dan F Critical one-tail yaitu: 2,1682516. Jika Fh < Ft maka Ho diterima. Hal ini berarti data variabel X (Pretest) dan Y (Post-test) Siklus I homogen.

Tabel D.4 F-Test Two-Sample for Variances Siklus II

\begin{tabular}{|c|c|c|}
\hline & Pretest & $\begin{array}{c}\text { Post-test Siklus } \\
\text { I }\end{array}$ \\
\hline Mean & 66,8 & 89,8 \\
\hline Variance & 121,9579 & 34,48421 \\
\hline Observations & 20 & 20 \\
\hline$d f$ & 19 & 19 \\
\hline$F$ & 1,53663 & \\
\hline$P(F<=f)$ one-tail & 0,004205 & \\
\hline F Critical one-tail & 2,168252 & \\
\hline
\end{tabular}

Kesimpulan yang didapat pada tabel di atas adalah: F adalah Fh (F-hitung) yaitu: 1,53663 dan F Critical one-tail yaitu: 2,168252. Jika Fh < Ft maka Ho diterima. Hal ini berarti data variabel X (Pretest) dan Y (Post-test) Siklus II homogen.

4. Hasil Uji Gain Skor Ternormalisasi

Proses pengujian data menggunakan Microsoft Excel 2007 seperti pada tabel 1.6 di bawah ini.

Tabel D.5 Gain Skor Ternormalisasi

\begin{tabular}{|ccccrr|}
\hline \multirow{2}{*}{$\begin{array}{c}\text { No Urut } \\
\text { Responden }\end{array}$} & Pretest & $\begin{array}{c}\text { Post-test } \\
\text { Siklus I }\end{array}$ & $\begin{array}{c}\text { Post-test } \\
\text { Siklus II }\end{array}$ & $\begin{array}{c}\text { Gain Skor } \\
\text { Siklus I }\end{array}$ & $\begin{array}{c}\text { Gain Skor } \\
\text { Siklus I }\end{array}$ \\
\cline { 2 - 6 } & Skor & Skor & Skor & \multicolumn{1}{c|}{ Skor } & \multicolumn{1}{c|}{ Skor } \\
\hline 1 & 72 & 88 & 92 & 0,571429 & 0,714286 \\
\hline 2 & 56 & 72 & 88 & 0,363636 & 0,727273 \\
\hline 3 & 80 & 88 & 96 & 0,4 & 0,8 \\
\hline 4 & 72 & 80 & 88 & 0,285714 & 0,571429 \\
\hline 5 & 60 & 68 & 88 & 0,2 & 0,7 \\
\hline 6 & 40 & 56 & 84 & 0,266667 & 0,733333 \\
\hline 7 & 85 & 96 & 100 & 0,733333 & 1 \\
\hline 8 & 60 & 68 & 80 & 0,2 & 0,5 \\
\hline 9 & 72 & 80 & 92 & 0,285714 & 0,714286 \\
\hline 10 & 80 & 88 & 100 & 0,4 & 1 \\
\hline 11 & 75 & 84 & 96 & 0,36 & 0,84 \\
\hline 12 & 76 & 88 & 96 & 0,5 & 0,833333 \\
\hline 13 & 76 & 84 & 92 & 0,333333 & 0,666667 \\
\hline 14 & 70 & 80 & 88 & 0,333333 & 0,6 \\
\hline 15 & 60 & 72 & 84 & 0,3 & 0,6 \\
\hline 16 & 60 & 76 & 80 & 0,4 & 0,5 \\
\hline 17 & 60 & 68 & 88 & 0,2 & 0,7 \\
\hline 18 & 70 & 76 & 92 & 0,2 & 0,733333 \\
\hline 19 & 56 & 76 & 84 & 0,454545 & 0,636364 \\
\hline 20 & 56 & 68 & 88 & 0,272727 & 0,727273 \\
\hline
\end{tabular}

Vol. 9 No. 2, Juni 2017

Madrasah homepage: http://ejournal.uin-malang.ac.id/index.php/madrasah/index 


\section{MADRASAH}

Jurnal Pendidikan dan Pembelajaran Dasar

p ISSN: 1979-5599 | e ISSN: 2502-194X

P a g e | 103

Dari tabel di atas dapat dijelaskan bahwa pada kegiatan pembelajaran siklus I dan siklus II perolehan gain skor ternormalisasi dikategorikan dalam tiga kategori seperti pada tabel 1.7 di bawah ini.

Tabel D.6 Data Distributif Frekuensi Gain Skor Ternormalisasi Siklus I dan II

\begin{tabular}{|ccccc|}
\hline Kategori & $\begin{array}{c}\text { Frekuensi } \\
\text { Siklus I }\end{array}$ & Prosentase & $\begin{array}{c}\text { Frekuensi } \\
\text { Siklus II }\end{array}$ & Prosentase \\
\hline$[<\mathrm{g}>] \geq 7$ : tinggi & 1 & $5 \%$ & 13 & $65 \%$ \\
\hline $\begin{array}{c}0,3 \leq[<\mathrm{g}>]<7: \\
\text { sedang }\end{array}$ & 11 & $55 \%$ & 7 & $35 \%$ \\
\hline$[<\mathrm{g}>]<0,3$ : rendah & 8 & $40 \%$ & 0 & $0 \%$ \\
\hline $\begin{array}{c}{[<\mathrm{g}>]<0 \text { tidak }} \\
\text { efektif }\end{array}$ & 0 & $0 \%$ & 0 & $0 \%$ \\
\hline
\end{tabular}

Dari tabel di atas dapat dijelaskan bahwa tingkat efektifitas pembelajaran dengan menggunakan model pembelajaran Treffinger dalam pembelajaran PKn pada SDN Bringin tahun pelajaran 2014/2015 sangat efektif untuk peningkatan prestasi belajar siswa yang ditunjukkan oleh nilai rata-rata posttest yang lebih besar dari pada pretest dan prosentase frekuensi Gain Skor ternormalisasi.

\section{Hasil Penelitian Antar Siklus}

Dijelaskan bahwa pada kegiatan pretest diperoleh nilai rata-rata prestasi belajar siswa adalah 66,80 dan ketuntasan belajar mencapai $55,00 \%$ atau ada 11 siswa dari 20 siswa sudah tuntas belajar. Hasil tersebut menunjukkan bahwa pada pra siklus secara klasikal siswa belum tuntas belajar, karena siswa yang memperoleh nilai $\geq 70$ hanya sebesar $55,00 \%$ lebih kecil dari persentase ketuntasan yang dikehendaki yaitu sebesar 85\%. Hal ini disebabkan karena siswa masih belum mengerti apa yang dimaksudkan dengan konsepsi sistem pemerintahan desa dan pemerintah kecamatan dan model pembelajaran Treffinger yang belum digunakan guru dalam proses belajar mengajar.

Lebih lanjut dijelaskan dari tabel di atas bahwa pelaksanaan siklus I diperoleh nilai rata-rata prestasi belajar siswa adalah 77,80 dan ketuntasan belajar mencapai 80,00 \% atau ada 16 siswa dari 20 siswa sudah tuntas belajar. Hasil ini menunjukkan bahwa pada siklus I ini ketuntasan belajar secara klasikal telah mengalami peningkatan sedikit lebih baik dari pretest. Hal ini disebabkan siswa masih merasa baru dan belum mengerti apa yang dimaksudkan dan digunakan guru dengan menerapkan model pembelajaran Treffinger. Disamping itu peningkatan hasil belajar siswa ini karena setelah guru menginformasikan bahwa setiap akhir pelajaran akan selalu diadakan tes sehingga pada pertemuan berikutnya siswa lebih termotivasi untuk belajar. Selain itu siswa juga sudah mulai mengerti apa yang dimaksudkan dan diinginkan guru dengan menerapkan model pembelajaran Treffinger.

\section{Refleksi Siklus I}

Dalam pelaksanaan kegiatan belajar mengajar diperoleh informasi dari hasil pengamatan sebagai berikut: (1) Guru kurang baik dalam memotivasi siswa dan dalam menyampaikan tujuan pembelajaran; (2) Guru kurang baik dalam melatih keterampilan Treffinger; (3) Guru kurang baik dalam pengelolaan waktu; dan (4) Siswa kurang begitu antusias selama pembelajaran berlangsung.

Vol. 9 No. 2, Juni 2017

Madrasah homepage: http://ejournal.uin-malang.ac.id/index.php/madrasah/index 


\section{Revisi Siklus I}

Pelaksanaan kegiatan belajar mengajar pada siklus I ini masih terdapat kekurangan, sehingga perlu adanya refisi untuk dilakukan pada siklus berikutnya. (1) Guru perlu lebih terampil dalam memotivasi siswa dan lebih jelas dalam menyampaikan tujuan pembelajaran. Dimana siswa diajak untuk terlibat langsung dalam setiap kegiatan yang akan dilakukan; (2) Guru perlu melatih keterampilan model pembelajaran Treffinger; (3) Guru perlu mendistribusikan waktu secara baik dengan menambahkan informasiinformasi yang dirasa perlu dan memberi catatan; dan (4) Guru harus lebih terampil dan bersemangat dalam memotivasi siswa sehingga siswa bisa lebih antusias.

Sedangkan pelaksanaan siklus II diperoleh nilai rata-rata tes formatif sebesar 89,80 dan terlihat sebanyak 20 siswa mencapai ketuntasan belajar. Maka secara klasikal ketuntasan belajar yang telah tercapai sebesar 100\% (termasuk kategori tuntas). Hasil pada siklus II ini mengalami peningkatan lebih baik dari siklus I. Adanya peningkatan hasil belajar pada siklus II ini dipengaruhi oleh adanya peningkatan kemampuan guru dalam menerapkan model pembelajaran Treffinger membuat siswa menjadi lebih terbiasa dengan pembelajaran seperti ini sehingga siswa lebih mudah dalam memahami materi yang telah diberikan.

Sebagaimana yang dilakukan pada siklus I maka pada siklus II ini juga dilakukan analisis data yang mendalam terhadap deskripsi data yang dipaparkan di atas. Dari analisis lembar observasi aktivitas siswa terjadi perubahan keaktifan yang signifikan. Pada siklus I sebagian siswa belum berani dalam menyampaikan gagasannya. Pada siklus II ini sebagian besar siswa sudah berani untuk bertanya dan mengungkapkan pendapatnya. Demikian juga dalam mengerjakan tugas kelompok atau diskusi, secara keseluruhan siswa sudah memperlihatkan aktivitas yang sangat baik. Siswa juga menunjukkan peningkatan dalam kemampuan memahami pokok bahasan nilai-nilai perumusan pancasila, secara keseluruhan siswa sudah mampu mengerjakan soal tes evaluasi secara optimal.

Selain itu keaktifan siswa di dalam pembelajaran pada siklus II ini meningkat terbukti dengan tingginya respon siswa terhadap pertanyaan yang diberikan guru, siswa menjawab pertanyaan guru dengan penuh semangat dan antusias. Siswa juga sudah bisa mengembangkan daya kreatifitas dan imajinasi mereka dengan baik, hal ini karena guru memberikan penjelasan alur untuk membuat kerangkanya. Keaktifan siswa yang meningkat secara signifikan tersebut terjadi karena kinerja guru yang semakin baik dari siklus I-II.

Guru dalam melaksanakan pembelajaran semakin mantap, luwes dan dapat menjelaskan materi dengan menyeluruh dan mendalam sehingga siswa lebih paham. Walaupun masih ada kekurangan-kekurangan kecil di antaranya kurang kontrol waktu, hal tersebut tidak menjadi penghambat berarti bagi peningkatan keaktifan dan hasil belajar siswa. Dengan demikian diketahui bahwa kemampuan memahami pokok bahasan sistem pemerintahan desa dan pemerintah kecamatan siswa kelas IV SDN Bringin, dapat ditingkatkan. Berdasarkan peningkatan kemampuan yang telah dicapai siswa, maka pelaksanaan Penelitian Tindakan Kelas (PTK) dianggap cukup dan diakhiri pada siklus II.

\section{Hubungan Antar Siklus}

Hubungan peningkatan kemampuan memahami sistem pemerintahan desa dan pemerintah kecamatan antar siklus dapat dibuktikan melalui hasil yang dijabarkan berikut ini: pada pretest siswa yang memperoleh nilai pada interval $\leq 69$ ada 9 siswa, $70-79$ ada 8 siswa, 80-89 ada 3 siswa, dan $\geq 90$ ada tidak ada siswa yang memperoleh nilai pada kelas interval tersebut. Sedangkan pada post-test siklus I siswa yang memperoleh nilai pada kelas

Vol. 9 No. 2, Juni 2017

Madrasah homepage: http://ejournal.uin-malang.ac.id/index.php/madrasah/index 


\section{MADRASAH}

Jurnal Pendidikan dan Pembelajaran Dasar

p ISSN: 1979-5599 | e ISSN: 2502-194X

P a g e | 105

interval $\leq 69$ ada 4 siswa, $70-79$ ada 5 siswa, $80-89$ ada 10 siswa, dan $\geq 90$ ada 1 siswa yang memperoleh nilai pada kelas interval tersebut.

Lebih lanjut dijelaskan bahwa pada pelaksanaan post-test siklus II yang memperoleh nilai pada kelas interval $\leq 69$ tidak ada siswa, 70-79 tidak ada siswa, 80-89 ada 11 siswa, dan $\geq 90$ ada 9 siswa. Dengan demikian dapat disimpulkan bahwa nilai kemampuan memahami sistem pemerintahan desa dan pemerintah kecamatan siswa dapat ditingkatkan melalui model pembelajaran Treffinger .

\section{Efektifitas penerapan model pembelajaran Treffinger.}

Penerapan model pembelajaran Treffinger pada mata pelajaran PKn pokok bahasan sistem pemerintahan desa dan pemerintah kecamatan dapat disimpulkan sangat efktif untuk meningkatkan prestasi belajar siswa kelas IV SDN Bringin tahun pelajaran 20142015. Hal ini dapat dibuktikan melalui hasil uji gain skor ternormalisasi dengan kriterian efektifitas tinggi (65\%), kriteria efektifitas sedang (35\%), efektifitas rendah (0\%) dan tidak efektif $(0 \%)$ dengan rata-sata gain skor ternormalisasi pada siklus I $(0,35)$ dan siklus II $(0,71)$

\section{Ketuntasan Hasil Belajar Siswa}

Melalui hasil penelitian ini menunjukkan bahwa model pembelajaran Treffinger memiliki dampak positif dalam meningkatkan prestasi belajar siswa. Hal ini dapat dilihat dari semakin mantapnya pemahaman siswa terhadap materi yang disampaikan guru (ketuntasan belajar meningkat dari pretest, post-test siklus I, dan post-test siklus II) yaitu masing-masing 55,00\%, 80,00\%, dan 100\%. Pada siklus II ketuntasan belajar siswa secara klasikal telah tercapai.

\section{Kemampuan Guru dalam Mengelola Pembelajaran}

Berdasarkan analisis data, diperoleh aktivitas siswa dalam proses pembelajaran menggunakan model pembelajaran Treffinger dalam setiap siklus mengalami peningkatan. Hal ini berdampak positif terhadap prestasi belajar siswa yaitu dapat ditunjukkan dengan meningkatnya nilai rata-rata siswa pada setiap siklus yang terus mengalami peningkatan yaitu pada pretest sebesar 66,80 , post-test siklus I sebesar 77,80, dan post-test siklus II sebesar 89,80 .

\section{Aktivitas Guru dan Siswa Dalam Pembelajaran}

Berdasarkan analisis data, diperoleh aktivitas siswa dalam proses pembelajaran memahami sistem pemerintahan desa dan pemerintah kecamatan dengan model pembelajaran Treffinger yang paling dominan adalah bekerja dengan menggunakan alat/media, mendengarkan/memperhatikan penjelasan guru, dan diskusi antar siswa/antara siswa dengan guru. Jadi dapat dikatakan bahwa aktivitas siswa dapat dikategorikan aktif.

\section{E. SIMPULAN}

Berdasarkan hasil pengolahan dan analisis data terhadap data hasil penelitian yang telah dilakukan mengenai implementasi model pembelajaran Treffinger untuk meningkatkan prestasi belajar siswa mata pelajaran PKn pada siswa kelas IV SDN Bringin Tahun Pelajaran 2014/2015 diperoleh kesimpulan:

Terdapat peningkatan hasil belajar siswa pada mata pelajaran PKn dalam pokok bahasan sistem pemerintahan desa dan pemerintah kecamatan dengan diterapkannya model pembelajaran Treffinger.

Vol. 9 No. 2, Juni 2017

Madrasah homepage: http://ejournal.uin-malang.ac.id/index.php/madrasah/index 
1. Peningkatan prestasi belajar siswa setelah mengikuti pembelajaran melalui model Treffinger meningkat secara signifikan. Hal ini ditunjukan dari hasil prhitungan rata-rata gain skor ternormalisasi dengan rata-rata nilai yaitu: siklus I $(0,35)$ berkretia sedang dan siklus II $(0,71)$ berkreteria tinggi.

2. Peningkatkan kemampuan memahami sistem pemerintahan desa dan pemerintah kecamatan pada siswa kelas IV SDN Bringin tahun pelajaran 2014/2015. Hal ini terbukti pada prasiklus nilai rata-rata kelas 66,80 dengan ketuntasan klasikal yang hanya mencapai 55,00\%. Kondisi tersebut mengalami peningkatan, pada siklus I, dimana nilai rata-rata kelas menjadi 77,80 dengan ketuntasan klasikal 80,00\%, dan siklus II nilai ratarata kelas menjadi 89,80 dengan ketuntasan klasikal 100\%. Dengan demikian penerapan model pembelajaran Treffinger dapat dilaksanakan untuk meningkatkan kualitas pembelajaran $\mathrm{PKn}$ pokok bahasan sistem pemerintahan desa dan pemerintah kecamatan di kelas IV SDN Bringin sehingga dapat meningkatkan kemampuan memahami sistem pemerintahan desa dan pemerintah kecamatan bagi siswa.

\section{REFERENSI}

Arikunto, Suharsimi. (2001). Prosedur Penelitian: Suatu Pendekatan Praktek. Jakarta: Rineka Branson. (1995). Terjemahan Syaripudin, dkk. Belajar "Civic Education" dari. Amerika. Yogyakarta: LKIS.

Departemen Pendidikan Nasional. (2006). Kurikulum Tingkat Satuan Pendidikan SD dan MI. Jakarta : Depdiknas

Huda, M. (2013). Model-model Pengajaran dan Pembelajaran. Yogyakarta: Pustaka Pelajar

Margono, S. (2005). Metodologi Penelitian Pendidikan.Jakarta: PT. Rineka Cipta

Moh. Nazir. (1999). Metode Penelitian. Jakarta: Ghalia Indonesia.

Permendiknas No.22 Tahun 2006. Tentang Standar Isi.

Samsuri. (2011). Pendidikan Kewarganegaraan sebagai Wahana Membangun Karakter Bangsa. Yogyakarta: UNY Press.

Sigit Dwi K. (2007). Pentingnya Pendidikan Moral bagi Anak Sekolah Dasar.Yogyakarta: UNY Press.

Sjarkawi. (2006). Pembentukan Kepribadian Anak. Jakarta: PT Bumi Aksara.

Sri Narwani. (2011). Pendidikan Karakter Pengintregasian 18 Nilai Pembentuk Karakter dalam Mata Pelajaran. Yogyakarta: Famelia.

Susilo, Kisyani. (2006). Penelitian Tindakan Kelas. Yogyakarta: Pustaka Book Publisher.

W.J.S. Poerwadarminta. (2002). Kamus Besar Bahasa Indonesia. Jakarta: Balai Pustaka

Vol. 9 No. 2, Juni 2017

Madrasah homepage: http://ejournal.uin-malang.ac.id/index.php/madrasah/index 